\title{
Modern combustion-electric PowerPack drive system design solutions for a hybrid two-unit rail vehicle
}

ARTICLE INFO

Received: 29 October 2021

Revised: 24 November 2021

Accepted: 9 December 2021

Available online: 27 December 2021
The article presents an innovative solution of a two-unit rail vehicle system for passanger transport with a dual-drive, diesel engine and electric motor. The vehicle was designed as a combination of two units, one dedicated to each of the two drive systems, where one unit provides electric drive while the other a combustion engine. The selection of engine and drive components was presented along with the aftertreatment systems used in the design. The provided solution was created in response to the dynamic needs of rail vehicle operators in the European Union who aim to reduce exhaust emissions without compomising the reach of the existing rail networks.

Key words: rail vehicles, combustion-electric drive, PowerPack, hybrid drive, dual-drive railbus

This is an open access article under the CC BY license (http://creativecommons.org/licenses/BY/4.0/)

\section{Introduction}

The ongoing global efforts to reduce the emissions of toxic and harmful compounds to the atmosphere resulted in a push towards new and innovative transport solutions. Transport as a branch of industry in 2016 contributed $30 \%$ of the total emissions of $\mathrm{CO}_{2}$ in the EU. Of which as much as $72 \%$ was generated by road vehicles, with rail vehicles contributing merely $0.5 \%$ [9]. This, however, means that out of the total 4432 million tons of $\mathrm{CO}_{2}$ equivalent emitted, in that year the transport sector contributed 1330 million tons, with road transport adding 957 million tons and rail transport adding about 6.65 million tons. Due to the clear dominance of road transport new and increasingly more strict regulations on exhaust emissions from road vehicles have been continuously introduced throughout the EU. These efforts culminated in new measurement methods and very stringent requirements to be met by all newly produced engines. This, however, resulted in many other forms of transport being left behind, and not receiving much legislative pressure to increase efficiency and innovate. Hence the development of new drive and propulsion technologies for rail vehicles has been slow, only recently resulting in some significant technological innovations, even though those are not yet ready for full commercial use.

One of the main aspects impacting rail vehicle operations, emissions, and applicability is the rail infrastructure. The simplest available solution to reduce exhaust emissions of $\mathrm{CO}_{2}$ from rail transport is switching to electric vehicles. This, however, is only possible for lines and routes that are fully electrified on all sections. Since the costs of electrification and maintenance of rail infrastructure are relatively high, levels of rail lines electrification in the EU vary greatly between member countries. While Switzerland has electrified all of its railway lines the EU-28 average in 2018 was only $54 \%$, where Poland was slightly above that average at $64 \%$. Due to the limited levels of railway lines electrification rail vehicles and locomotives with combustion engines remain necessary $[1,19]$. This, however, might change, as new technologies and drive system solutions become more prevalent.

Aside from the newest technologies in rail propulsion systems, such as hydrogen fuel cells [7], most working solutions that can avoid the problems resulting from nonelectrified railways, while still reducing $\mathrm{CO}_{2}$ emissions, include some form of drive hybridization [5, 10]. This means combining a conventional diesel engine system with an electric drive system [3], preferably along with some energy storage and recovery capabilities [4]. Hybrid drives are a proven solution with a long history of use, especially in road vehicles, and clear advantages. Their use in rail vehicles is sometimes made difficult due to the space limitations. The article presents a new solution two-unit hybrid drive solution for passenger rail vehicles, designed by the Łukasiewicz Research Network's Rail Vehicles Institute "TABOR" as a modern solution to the problem of insufficient railway electrification. A design using two opposing combustion engines with generators was discussed and presented along with the drive system components and subcomponents, including the exhaust emissions aftertreatment systems for the equipped combustion engines.

\section{Internal combustion vehicle standards}

\subsection{European standards}

The source of energy in modular drive systems is an internal combustion engine in most cases, which, due to its nature of operation, emits harmful substances into the atmosphere resulting from the fuel combustion process [6, $15,16,21,22]$. In order to reduce the environmental impact of vehicles equipped with internal combustion engines, exhaust emission limits were introduced. Currently, these standards are becoming increasingly more restrictive, forcing producers to use advanced technologies that reduce the engine emissions. The permissible values along with the measurement methods and procedures were defined that varied depending on the vehicle type, its technical parameters, and the country for which it was being approved. 
European regulations apply in the European Union and the European Economic Area. The Euro exhaust emission standards (labeled from 1 to 6) introduce limits for PC (Passenger Car) and LDV (Light Duty Vehicle) vehicle types and distinguish between two types of ignition, i.e. spark-ignition and compression-ignition, as well as the type of fuel used. Normative documents relating to compression ignition engines have more restrictive limit values for carbon monoxide $\mathrm{CO}$ and nitrogen oxides $\mathrm{NO}_{\mathrm{x}}$ compared to spark ignition engines, which is dictated by the nature of their operation. In addition, compression ignition engines from Euro 1 require compliance with the particulate matter exhaust emission limits (for spark ignition engines this was added along with the Euro 5 standards). The latest regulations also enforce a control test of the particle number generated in operation. From Euro 6c, exhaust emissions are tested on the basis of the WLTC (Worldwide Harmonized Light Vehicles Test Cycle) test, replacing the previous NEDC (New European Driving Cycle) test. Currently, laboratory tests are supplemented by tests in real operating conditions (Real Driving Emissions - RDE) performed with the use of portable measuring equipment belonging to the PEMS (Portable Emissions Measurement System) category (Fig. 1).

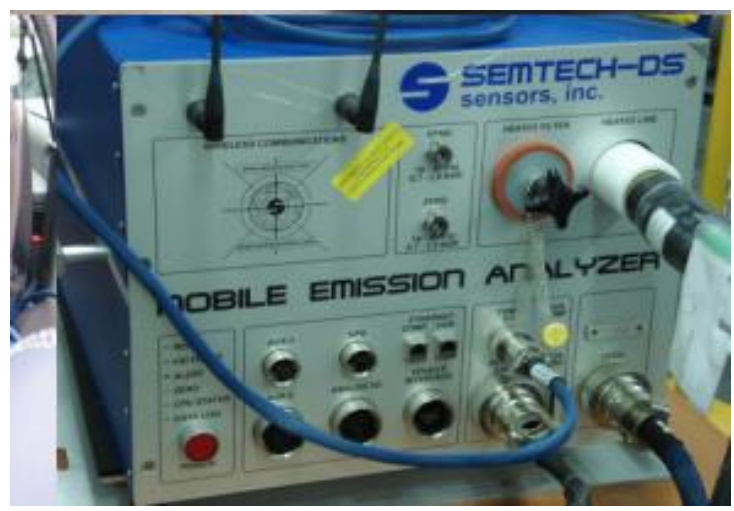

Fig. 1. Example of a PEMS device - SEMTECH DS [17]

European regulations for HDVs (Heavy Duty Vehicles) are included in Euro I-VI standards. The Euro VI standard introduced an emission measurement procedure carried out using the WHSC (World Harmonized Stationary Cycle) and WHTC (World Harmonized Transient Cycle) tests. These tests are standardized test procedures for the European Union, the United States, Japan and Australia. The last normative document (Euro VI) also changed the regulations regarding the control of conformity in operation. Also in the case of heavy vehicles, tests are currently required in real road conditions measured using PEMS type equipment.

The exhaust emission standards also apply to combustion engines used in off-road applications, in the standard defined as Stage I-V. Over time these limits gradually became more and more restrictive (Fig. 2). Exhaust emission limit values for rail traction engines were being introduced from Stage III onwards, split into the Stage IIIA and Stage IIIB standards. They contain a separate category for diesel engines used in locomotives (category $\mathrm{R}, \mathrm{RL}, \mathrm{RH}$ ) and in railcars (category $\mathrm{RC}$ ). The applicable test procedure for testing in accordance with the Stage I-IIIA is the NRSC
(Non-Road Stationary Cycle). From Stage IIIB and IV onwards, it is also necessary to meet the emission limits in the NRTC (Non-Road Transient Cycle) test (Fig. 3).

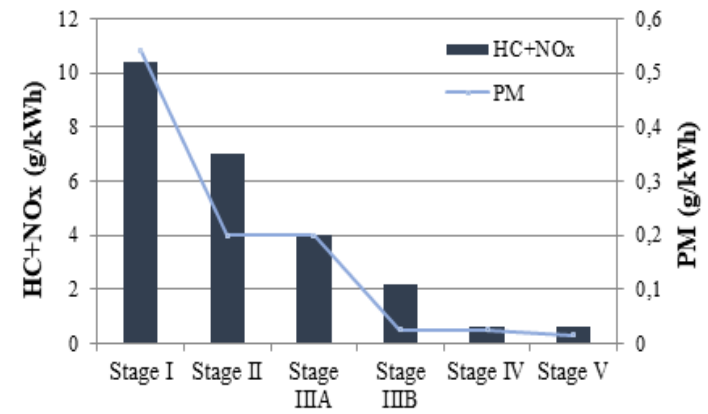

Fig. 2. Stage $\mathrm{I}-\mathrm{V}$ emission limits for $\mathrm{NRMM}$ vehicles $(130 \mathrm{~kW} \leq \mathrm{P} \leq 560$ $\mathrm{kW})[18]$

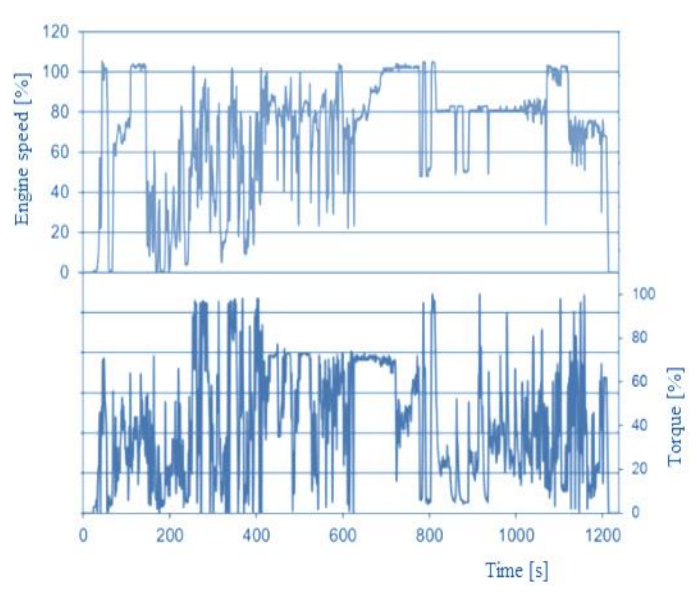

Fig. 3. The NRTC test procedure parameters [18]

\subsection{American and Japanese standards}

The exhaust emission standards for locomotives in the US take into account newly manufactured and modernized locomotives. There is a division into engines running on diesel and other fuels. The regulations are specified in the documents called Tier 0-4. In 2008, the previously set values in the Tier 0-2 standards were tightened. In addition, new requirements included in Tier 3 and Tier 4 were also introduced. For the test procedure the pollutant emission is measured during a 10-phase static test, which differs in the proportion of individual phases depending on the vehicle category, i.e. shunting and linear locomotives.

In Japan, the emission limits for internal combustion engines used in off-road vehicles and machines apply to the 19 to $560 \mathrm{~kW}$ power range. The vehicles are split into two groups, i.e. registered vehicles and unregistered vehicles. The exhaust emission standards for both categories are identical, but have been introduced by separate legal acts. The limit values for 2006-2008 were developed based on the US Tier standards, while in 2008 a tightening of the limits was ordered based on the provisions of Tier 4 Interim/Stage IIIB (in 2011-2013) and Tier 4/Stage IV (in 2015-2016). Emission measurements are performed in accordance with the JIS B 8001-1 8-phase test. For standards introduced in 2008, there is also an additional requirement to perform an NRTC test. Figure 4 shows the emission standards applicable in individual countries around the world. 


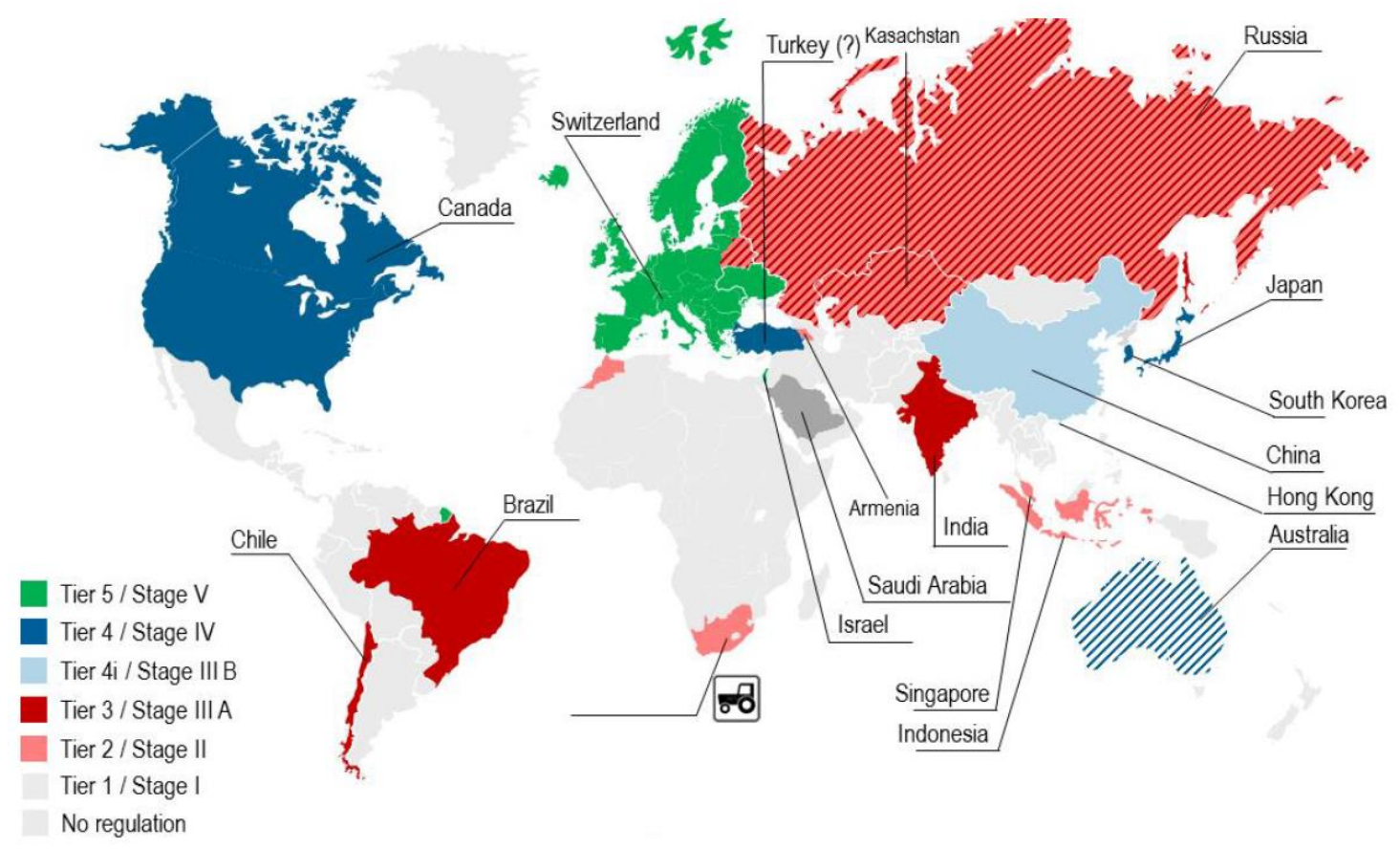

Fig. 4. Emission standards in individual countries [8]

\section{Powerpack drive systems}

A PowerPack is defined as a group of systems that are a part of an easily replaceable module that connects the engine (most often an internal combustion engine, but other types of drive units, e.g. electric motors, are becoming increasingly popular), along with a gearbox and other mechanisms necessary for the vehicle drive system to function properly. This system is used in many types of industrial equipment designs, as well as in various means of transport. The most common application is the use of this type of solution in the military industry (Fig. 5), i.e. armored vehicles, varying from tanks to armored infantry vehicles [10, 23].

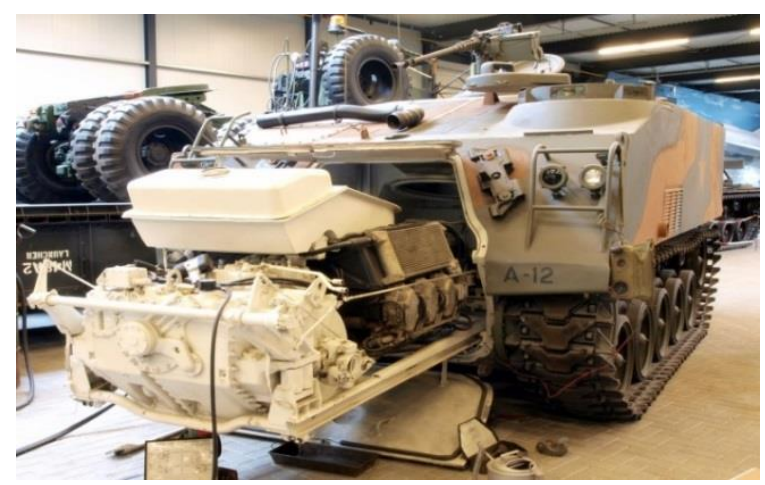

Fig. 5. Removal of the Powerpack system from the M75 APC infantry transport vehicle [11]

Taking into account the many advantages that characterize PowerPack systems, it is expected that in the future manufacturers of leading industries and transport sectors will increase their use of such solutions. Many internal combustion vehicles, due to their high degree of wear and tear, undergo or will undergo thorough modernization, which also includes a modernization of their drive systems.
Replacing the drive unit with a modular one, and the easier access for maintenance service that comes with it, makes this type of a solution more popular. Recently, modernization projects have been developed for the T-72 and PT-91 tanks. These projects use Renk's PowerPack systems with the designation 350S [12] (Fig. 6).

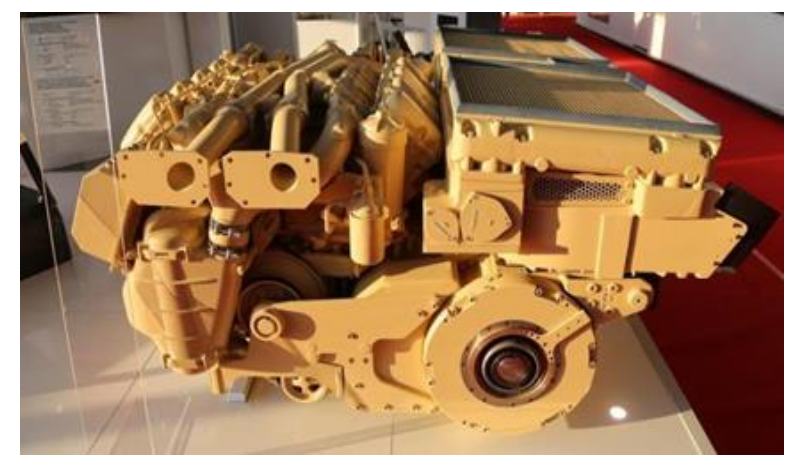

Fig. 6. Renk's PowerPack systems with the designation 350S [12]

The Powerpack system is also used in other branches of the industry, where such systems are often used as stationary energy generators. This solution has also been widely adopted in marine transport, where modular drive systems are used in seaworthy vessels such as yachts and ferries (Fig. 7). The power provided by such a Powerpack module can reach even up to $8000 \mathrm{~kW}$, as shown by the example offered by MTU solutions [14, 20].

Modular drive systems are also becoming a standard element when designing new rail vehicles (Fig. 8). Hybrid solutions such as diesel-electric, meaning an internal combustion engine with a mechanical drive or with a hydraulic drive, are growing in popularity in this branch of transport. PowerPacks designed for rail transport are distinguished by a relatively flat, compact structure suitable for installation under the floor or on the roof of an existing vehicle [20]. 
The company that has significantly developed this technology and its applications for rail transport is MTU. The manufacturer offers systems capable of generating power of up to $700 \mathrm{~kW}$ in the case of the MTU PowerPack Series 1600 (Fig. 9).

The main advantages of using a PowerPack module include:

- modularity, it distinguishes the drive system from other types of drives,

- configuration that resembles Plug \& Play which enables quick and easy installation as well as disassembly for maintenance or replacement with another module unit.

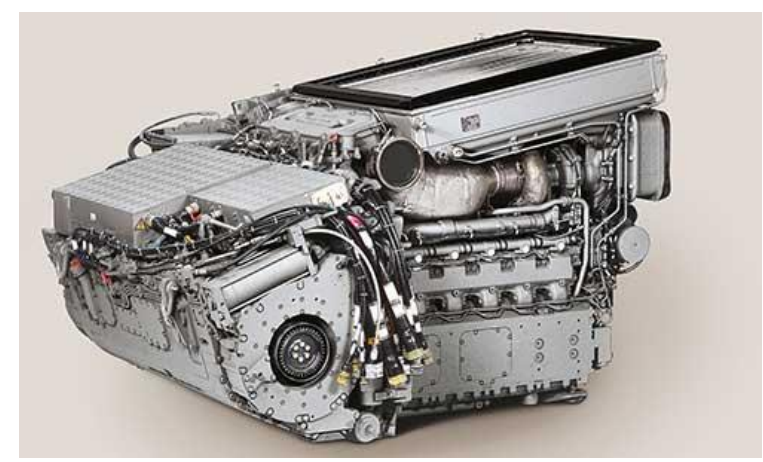

Fig. 7. MTU series 890 PowerPack [20]

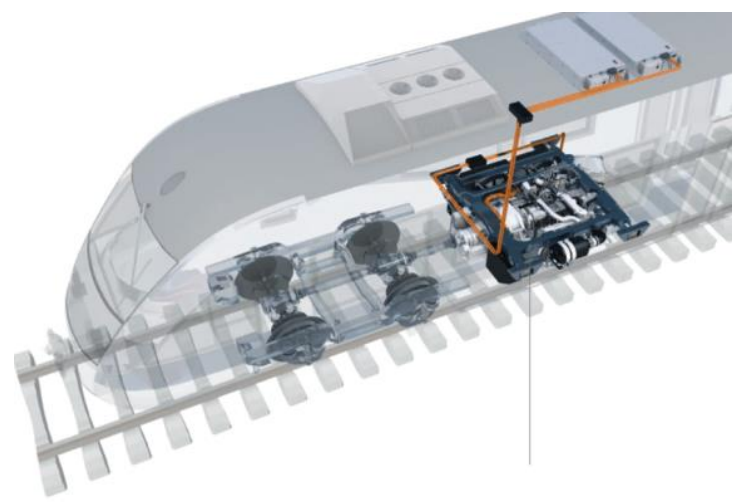

Fig. 8. Powerpack from the MTU company designed for railbus applications [20]

As a result the operating time loss during maintenance or replacement is minimized and the running costs of the vehicle decrease,

- compact arrangement of drive system elements significantly reduces the weight of the whole module,

- real-time monitoring and regulation of operation using the electronic engine management system,

- hybrid systems are characterized by an environmentally friendly drive solution with proven technology and an optimized combustion process,
- PowerPack modules are equipped with aftertreatment and other technologies that enable the reduction of toxic compounds generated in the combustion process [2, 13].

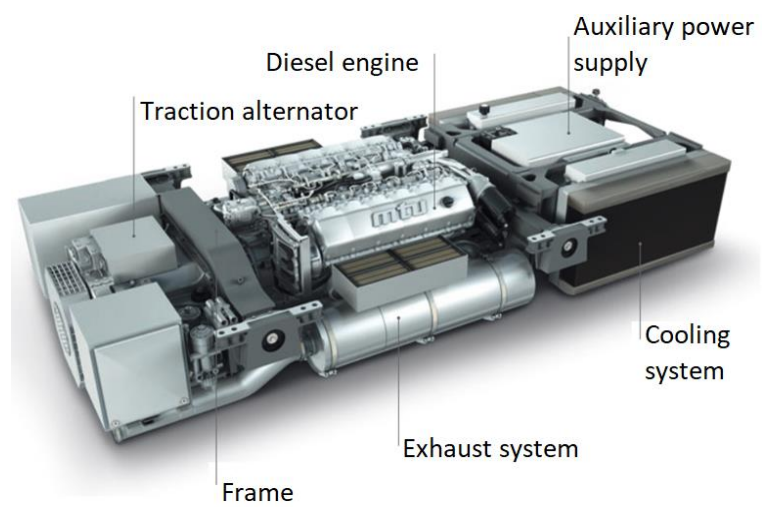

Fig. 9. MTU series 1600 PowerPack [20]

\section{227M railcar powerpack drive systems}

\subsection{M railcar}

Due to the requirements for meeting stringent exhaust emission standards and modern design solutions, the railway industry used a solution resulting from these two factors.

One of the vehicles in which the Powerpack solution was used is the 227M railcar. In September 2021, FPS H. Cegielski presented a new rail vehicle from the Plus platform for the first time. It is a hybrid vehicle equipped with the EPS PowerPack system that focuses on ecology and technological development. Modular drive solutions are increasingly more often used in public and freight transport. As an example, a railbus for regional passenger transport was designed by Łukasiewicz Research Network - Rail Vehicles Institute "TABOR". The two-unit vehicle is innovative due to the use of two different propulsion sources (Fig. 10). One of the vehicle units is driven using an electric motor. When driving in electric mode, energy is drawn from the electric traction via the pantograph. In the event of a breakdown of the overhead line or its absence, the vehicle can switch to the diesel mode thanks to the installation of two internal combustion engines with power generators in the other unit. This means that the described vehicle can travel on both electrified and non-electrified routes.

The vehicle rests on four bogies. Two of them are trolleys that are located at the fronts of the two units. The other two are motor bogies which are located close to the consist connection points on the units back. Electric motors are mounted on the motorized bogies, which are powered using the electric traction when driving in electric mode or from a generator set when in the diesel driving mode. The generator set was installed in the Diesel unit between the driver's compartment and the passenger compartment (Fig. 11).

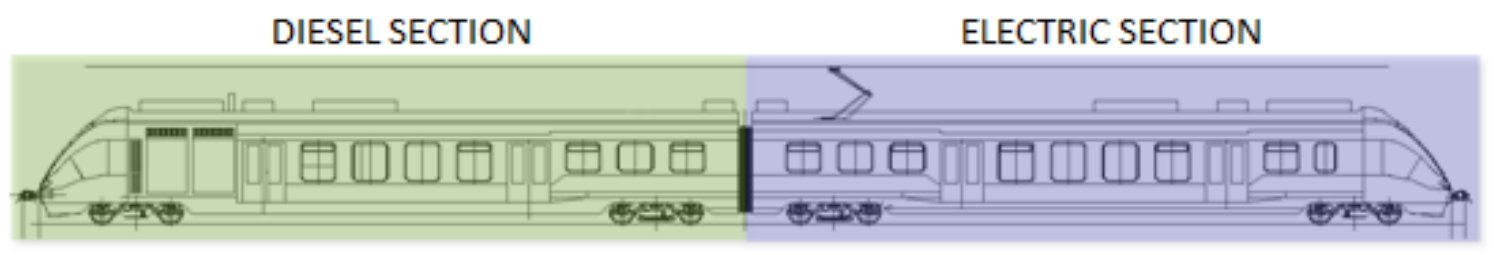

Fig. 10. Diesel and Electric modules of the type 227M rail vehicle 


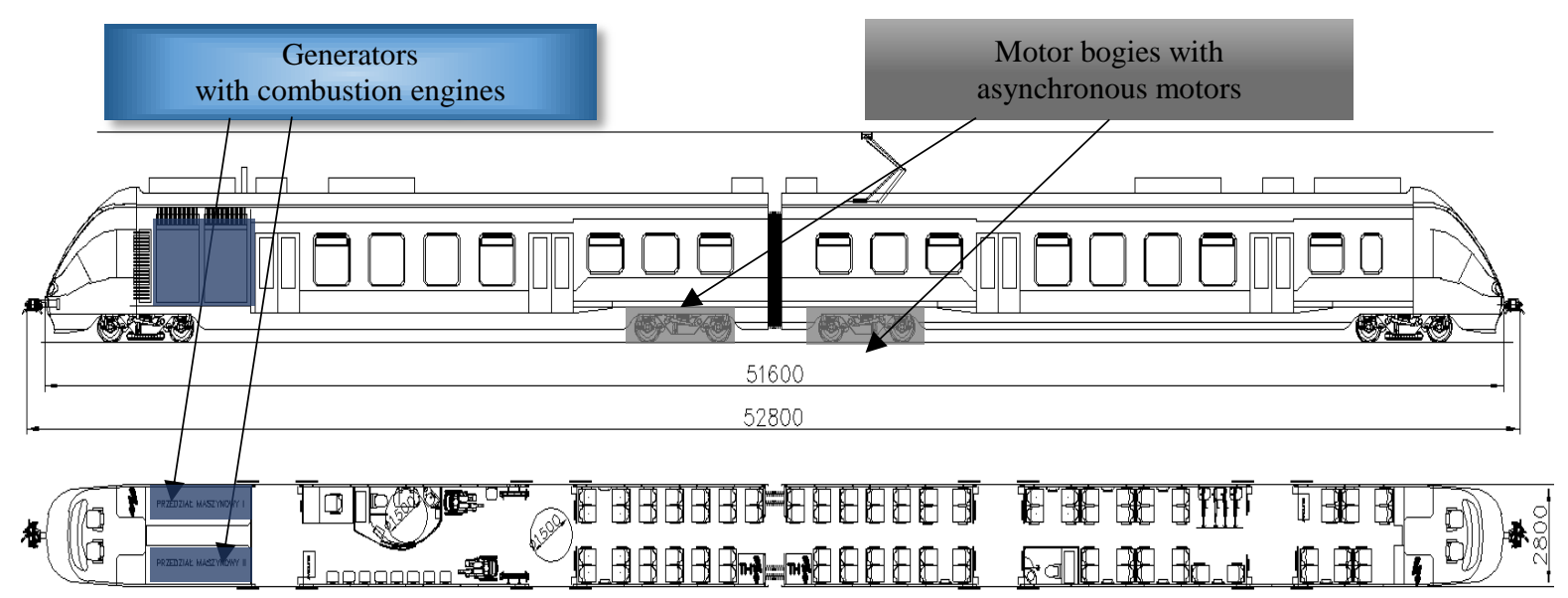

Fig. 11. Location of generating sets and motor bogies

\subsection{Engine unit}

The machinery space consists of two generating sets installed on the sides of the vehicle and is separated by a corridor leading to the driver's cab. In the case of driving using the diesel drive mode, the drive is powered using two TCD 12.0 L6 diesel engines by Deutz with a power of 400 $\mathrm{kW}$ (Fig. 12). Table 1 shows the data relating to the drive unit and on Fig. 13 presents dimensions of the engine.

Table 1. Data sheet for the Deutz TCD 12.0 L6 engine unit

\begin{tabular}{|c|c|c|}
\hline Engine data & TCD 12.0 L6 & Unit \\
\hline Engine type & $\begin{array}{l}\text { Compression-ignition four- } \\
\text { stroke engine }\end{array}$ & {$[-]$} \\
\hline Turbocharging & $\begin{array}{l}\text { Turbocharger with charge } \\
\text { air cooling }\end{array}$ & {$[-]$} \\
\hline Cooling type & water cooled & {$[-]$} \\
\hline Cylinder layout & In-line & {$[-]$} \\
\hline Cylinder number & 6 & {$[-]$} \\
\hline Piston diameter/stroke & $130 / 150$ & {$[\mathrm{~mm}]$} \\
\hline Total engine displacement & 11946 & {$\left[\mathrm{~cm}^{3}\right]$} \\
\hline Supply system & Common Rail & {$[-]$} \\
\hline $\begin{array}{l}\text { Exhaust gas aftertreatment } \\
\text { system (EU Category V) }\end{array}$ & $\begin{array}{c}\text { Diesel Oxidation Catalyst } \\
\text { (DOC) + Selective Catalytic } \\
\text { Reduction (SCR) + Diesel } \\
\text { Particulate Filter (DPF) }\end{array}$ & {$[-]$} \\
\hline Number of valves per cylinder & 4 & {$[-]$} \\
\hline Valve clearance: inlet/outlet & $0.3^{ \pm 0.05} / 0.4^{ \pm 0.05}$ & {$[\mathrm{~mm}]$} \\
\hline Order of ignition & $1-5-3-6-2-4$ & {$[-]$} \\
\hline $\begin{array}{l}\text { Direction of rotation looking at } \\
\text { the flywheel }\end{array}$ & left & {$[-]$} \\
\hline $\begin{array}{l}\text { Engine power according to ISO } \\
9249\end{array}$ & 400@1900 rpm & {$[\mathrm{kW}]$} \\
\hline Max torque & 2500@1200 rpm & {$[\mathrm{Nm}]$} \\
\hline $\begin{array}{l}\text { Coolant quantity (only engine } \\
\text { without radiator/hoses and } \\
\text { pipes) }\end{array}$ & $\approx 24$ & {$\left[\mathrm{dm}^{3}\right]$} \\
\hline $\begin{array}{l}\text { Allowable permanent } \\
\text { coolant temperature }\end{array}$ & $\max 110$ & {$\left[{ }^{\circ} \mathrm{C}\right]$} \\
\hline $\begin{array}{l}\text { Quantity of oil during oil } \\
\text { change (with filter) }\end{array}$ & $\approx 41.5$ & {$\left[\mathrm{dm}^{3}\right]$} \\
\hline $\begin{array}{l}\text { Oil sump temperature, maxi- } \\
\text { mum }\end{array}$ & 130 & {$\left[{ }^{\circ} \mathrm{C}\right]$} \\
\hline $\begin{array}{l}\text { Oil pressure minimum (low } \\
\text { idle, warm engine) }\end{array}$ & $170 / 1.7$ & {$[\mathrm{kPa} / \mathrm{bar}]$} \\
\hline $\begin{array}{l}\text { Maximum permissible air } \\
\text { temperature downstream of the } \\
\text { boosted air cooler }\end{array}$ & 60 & {$\left[{ }^{\circ} \mathrm{C}\right]$} \\
\hline $\begin{array}{l}\text { Weight without cooling system } \\
\text { according to DIN 70020-A }\end{array}$ & $\approx 1005 \pm 3.5 \%$ & {$[\mathrm{~kg}]$} \\
\hline
\end{tabular}

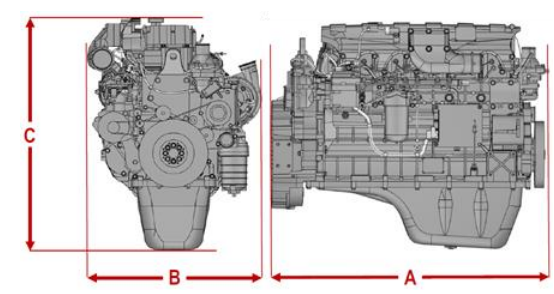

Fig. 12. Deutz TCD 12.0 L6 engine unit dimensions: A - $1335 \mathrm{~mm}$, B - $853 \mathrm{~mm}, \mathrm{C}-1156 \mathrm{~mm}[8]$
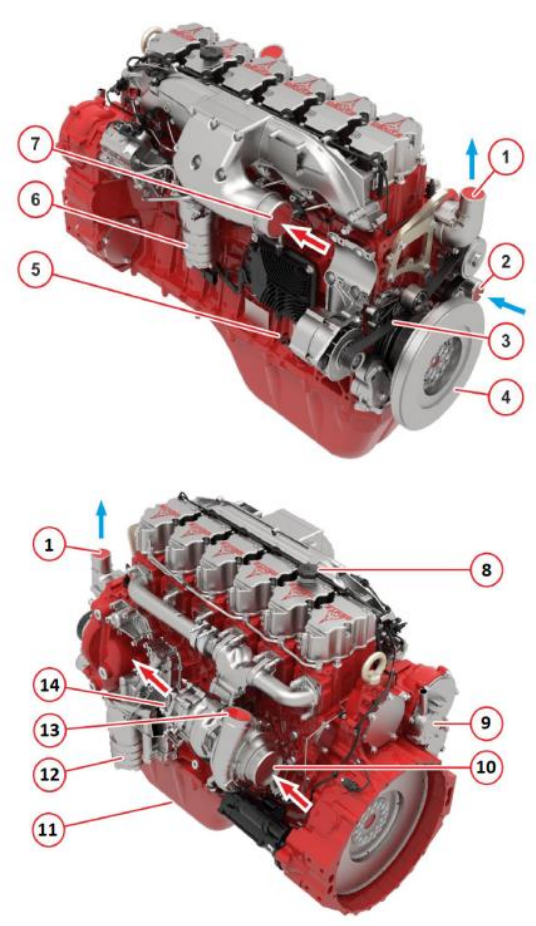

Fig. 13. Engine structure: 1 - coolant outlet, 2 - coolant inlet, 3 - v-rib belt, 4 - torsional vibration damper, 5 - oil dipstick, 6 - fuel filter, 7 - boost air intake, 8 - oil inlet, 9 - engine block ventilation, 10 - air inlet, 11 - oil drain plug, 12 -lubricating oil filter, 13 -boost air outlet, 14 - exhaust [8]

\subsection{Generator}

While driving in the combustion engine mode, the diesel engines drive the Emit GTds500S4A generator with a rated apparent power of $460 \mathrm{kVA}$. There are two devices of this type on the vehicle, which supply electricity to four 
traction electric motors installed on the vehicle bogies. Specifications for the GTds500S4A generator were shown in Table 2.

Table 2. Technical specifications of the GTds500S4A generator

\begin{tabular}{|l|c|c|}
\hline Data & Value & Unit \\
\hline Engine type & GTds500S4A & {$[-]$} \\
\hline Rated power & 460 & {$[\mathrm{~kW}]$} \\
\hline Rated speed & 1800 & {$[\mathrm{rpm}]$} \\
\hline Rated voltage & $3000 \pm 5 \%$ & {$[\mathrm{~V}]$} \\
\hline Rated frequency & $60 \pm 2 \%$ & {$[\mathrm{~Hz}]$} \\
\hline Rated current & 88.5 & {$[\mathrm{~A}]$} \\
\hline Efficiency & 93 & {$[\%]$} \\
\hline Mass & 1850 & {$[\mathrm{~kg}]$} \\
\hline Operating temperature & From -30 to +40 & {$\left[{ }^{\circ} \mathrm{C}\right]$} \\
\hline Stator winding connection & Star & {$[-]$} \\
\hline Insulation class & $\mathrm{H}(\mathrm{VPI})$ & {$[-]$} \\
\hline
\end{tabular}

The space behind the driver's cabin in the Diesel Unit is provided for the installation of the combustion engine with the traction generator and the exhaust gas aftertreatment system. Because the engine can only be accessed from the side, it was necessary to invert the entire engine-generator system (Fig. 14).

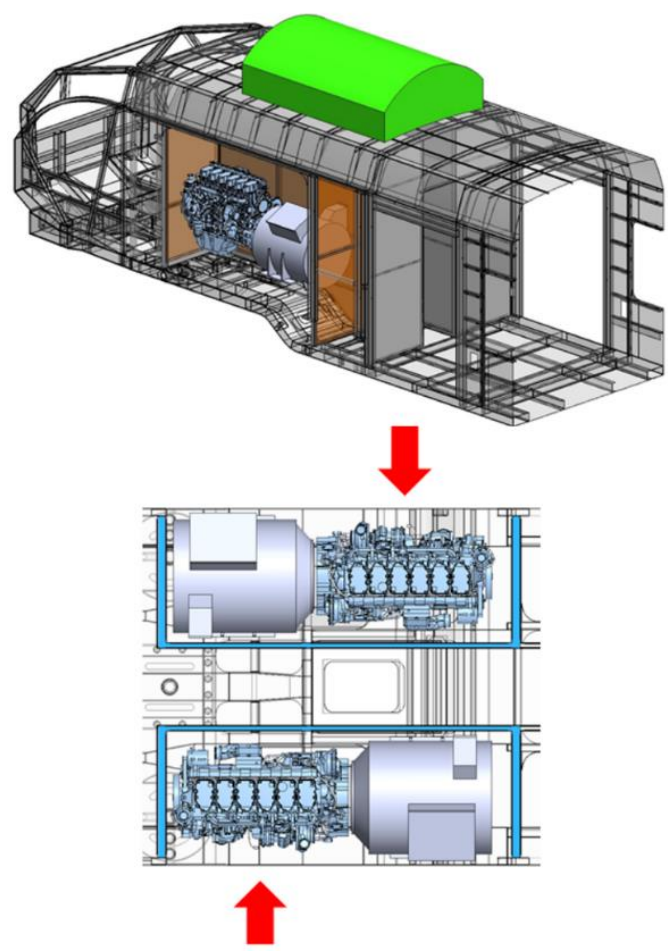

Fig. 14. Location of machine room spaces; red arrows indicate the direction from which it will be possible to access and service the engine and the traction generator (top view)

\subsection{Exhaust aftertreatment system}

The combustion drive system met the Stage V exhaust emission standard. In order to achieve this level of exhaust emission reduction, it was necessary to use a sophisticated exhaust aftertreatment system. The exhaust system consisted of: Selective Catalytic Reduction (SCR), Diesel Particulate Filter (DPF), and Diesel Oxidation Catalyst (DOC). The complete exhaust aftertreatment system was shown in Fig. 15.

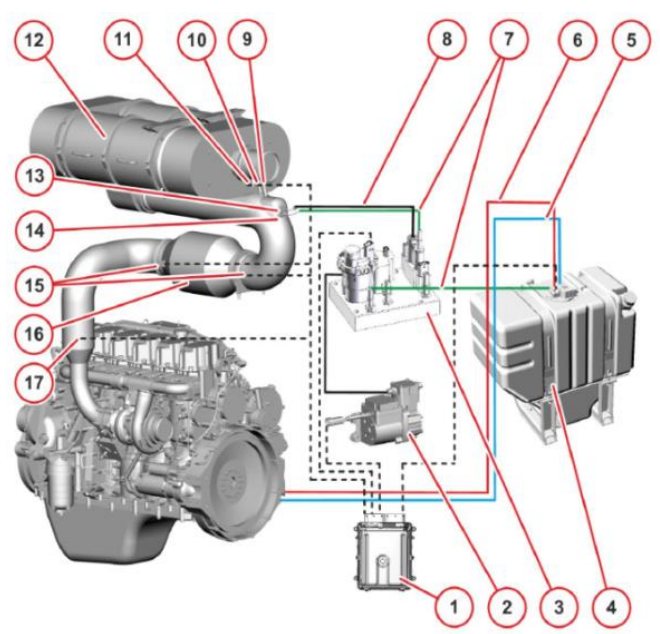

Fig. 15. Exhaust aftertreatment system: 1 - engine control module, $2-$ SCR compressor, 3 - SCR pump, 4 - SCR tank, 5 - coolant line, dispenser, 6 - pre-heating line, SCR tank, 7 - SCR line, 8 - AdBlue ${ }^{\circledR}$ injection air supply line, $9-\mathrm{NH}_{3}$ sensor, $10-\mathrm{NO}_{\mathrm{x}}$ sensor, 11 - temperature sensor, 12 - SCR catalyst with a particulate filter (DPF), 13 - air access connection points, 14 - SCR injector, 15 - temperature sensor, 16 - Diesel Oxidation Catalyst (DOC), $17-\mathrm{NO}_{\mathrm{x}}$ sensor [8]

\subsection{Machine room}

The combustion drive system powerpack is mounted on the $227 \mathrm{M}$ vehicle and is the source of electricity for the traction motors. Thanks to this solution, the rail vehicle is able to reach a travel speed of $120 \mathrm{~km} / \mathrm{h}$ while operating using the internal combustion engine. The generators can be accessed by removing the side panel from the outside of the vehicle. Figures 16 shows machine room and components of the combustion generator. Figure 17 shows the powerpack and its location in the real vehicle.

\section{Summary}

The limited electrification of railways in Poland and many other EU member states necessitates employment of a mixed rolling stock, including both combustion engine drive systems as well as electric drive systems supplied by overhead power lines. This solution ceases to be viable when pressure is put on the reduction of the size of rolling stock powered by combustion engines. This, however, has become the reality for most operators as continued legislative efforts by the European Union and the EU Parliament require a steady reduction in the amounts of $\mathrm{CO}_{2}$ emitted into the atmosphere to combat global warming. Additionally reduced limit values for the emission of toxic exhaust components demand innovation, both in the field of drive systems and exhaust aftertreatment solutions. Thus, as a response to the growing market needs, various rolling stock producers offer new solutions that are to satisfy the changing landscape of rail vehicles. One of such solutions, discussed in this article, was the $227 \mathrm{M}$ railbus. It is a two-unit hybrid solution, utilizing a dual-drive system separated between the two units. The combustion unit is equipped with two diesel engine-generator sets and each unit has one motor bogie with asynchronous motors for electric propulsion. The combined drive systems allow the vehicle to travel through rail lines that have only partial electrification, as well as enable options of better energy management during driving thanks to the addition of the electric drive. 

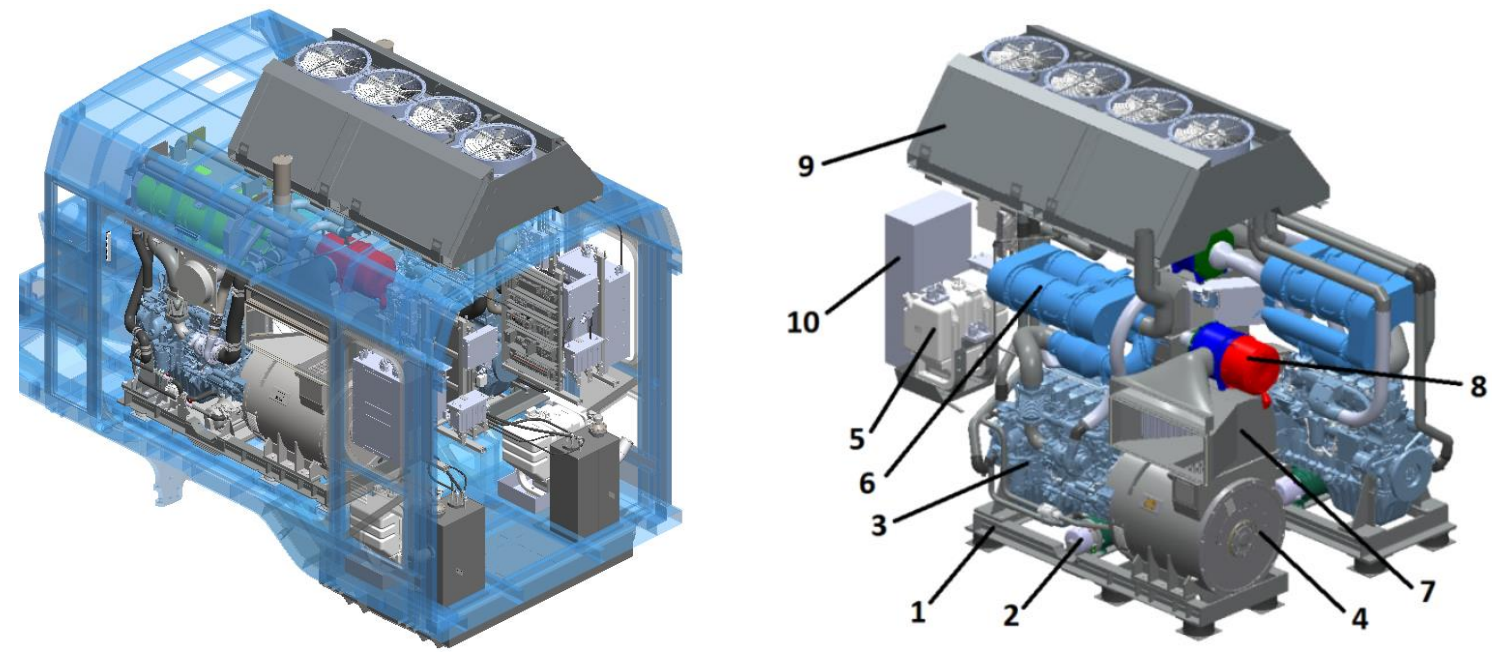

Fig. 16. Left: Machine room. On the right: components of the combustion generator: 1 - generator frame, 2 - heater, 3 - combustion engine, 4 - traction generator, 5 - AdBlue tank, 6 - exhaust aftertreatment system with mufflers, 7 - ventilation duct of the traction generator, 8 - intake air filter with a duct, 9 - cooling system for two engines, 10 - engine control module space
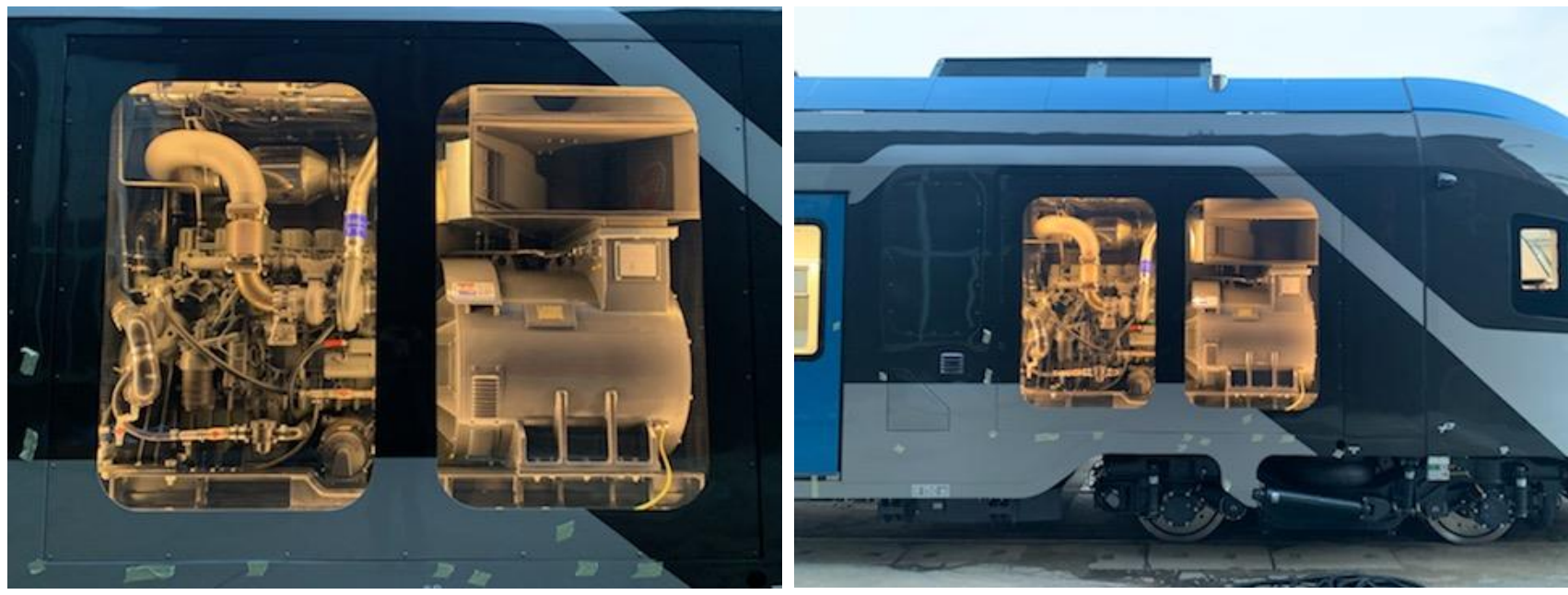

Fig. 17. Engine-generator unit of 227M railcar and 227M rail vehicle with drive unit

\section{Acknowledgements}

This work was supported by the Applied Research Program No. PBS3/B6/26/2015 entitled: "Light rail bus for regional traffic" and co-financed by the National Centre for Research and Development.

\section{Nomenclature}

DOC Diesel Oxidation Catalyst

DPF Diesel Particulate Filter

EU European Union

HDV Heavy Duty Vehicles

LDV Light Duty Vehicle

NEDC New European Driving Cycle

NRSC Non-Road Stationary Cycle

NRTC Non-Road Transient Cycle
PC Passenger Car

PEMS Portable Emissions Measurement System

RDE Real Driving Emissions

SCR Selective Catalytic Reduction

US United States of America

WHSC World Harmonized Stationary Cycle

WHTC World Harmonized Transient Cycle

WLTC Worldwide Harmonized Light Vehicles Test Cycles

\section{Bibliography}

[1] ANDRZEJEWSKI, M., DASZKIEWICZ, P., URBAŃSKI, P. et al. Impact of a locomotive engine modernization on fuel consumption. MATEC Web of Conferences. EDP Sciences. 2021, 338, 01001.

https://doi.org/10.1051/matecconf/202133801001

[2] Biuro Handlowe RUDA Sp. z o.o. Sp. k. materials

[3] BARBOSA, F.C. Hybrid rail technology review: an intermediate pathway for electrifying the freight and commuter rail sector-a technical and operational assessment. ASME/IEEE Joint Rail Conference. American Society of Mechanical Engineers. 2021, V001T07A001. https://doi.org/10.1115/JRC2021-58271 
[4] CIPEK, M., PAVKOVIĆ, D., KLJAIĆ, Z. et al. Assessment of battery-hybrid diesel-electric locomotive fuel savings and emission reduction potentials based on a realistic mountainous rail route. Energy. 2019, 173, 1154-1171.

https://doi.org/10.1016/j.energy.2019.02.144

[5] DASZKIEWICZ, P., ANDRZEJEWSKI, M., MEDWID, M. et al. Analysis of the selection of chosen technical parameters of the powertrain system for a diesel-electric rail-road tractor. Combustion Engines. 2021, 186(3), 64-71. https://doi.org/10.19206/CE-140723

[6] DASZKIEWICZ, P., ANDRZEJEWSKI, M., URBAŃSKI, P. et al. Analysis of the exhaust emissions of toxic compounds from a special purpose rail machine PŁT-500 during profiling the ballast cess. Journal of Ecological Engineering. 2021, 22(7), 80-88.

https://doi.org/10.12911/22998993/139214

[7] DASZKIEWICZ, P., KURC, B., PIGŁOWSKA, M. et al. Fuel cells based on natural polysaccharides for rail vehicle application. Energies. 2021, 14(4), 1144. https://doi.org/10.3390/en14041144

[8] Deutz company materials

[9] European Parliament Infographics https://www.europarl.europa.eu

[10] HERWARTZ, S., PAGENKOPF, J., STREUling, C. Sector coupling potential of wind-based hydrogen production and fuel cell train operation in regional rail transport in Berlin and Brandenburg. International Journal of Hydrogen Energy. 2021, 46(57), 29597-29615. https://doi.org/10.1016/j.ijhydene.2020.11.242

[11] HUNNICUTT, R.P. Pershing: a history of the medium tank T20 series. Feist Publications. Berkeley, California 1971.

[12] Defence24. https://www.defence24.pl

[13] Flickr. https://www.flickr.com

[14] K\&W DRIVE SYSTEMS. https://www.kwds.at

[15] KAMIŃSKA, M., RYMANIAK, Ł., LIJEWSKI, P. et al. Investigations of exhaust emissions from rail machinery dur-

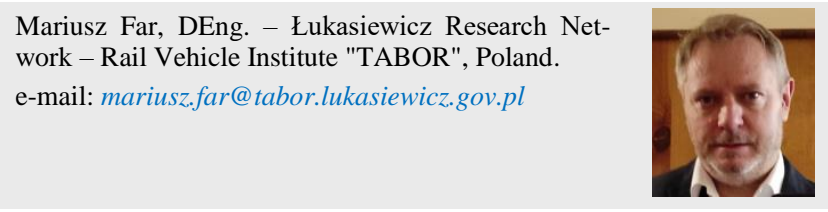

Patryk Urbański, MEng. - Łukasiewicz Research Network - Rail Vehicle Institute "TABOR", Poland. e-mail: patryk.urbanski@tabor.lukasiewicz.gov.pl

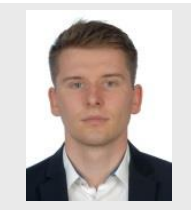

ing track maintenance operations. Energies. 2021, 14(11), 3141. https://doi.org/10.3390/en14113141

[16] LIJEWSKI, P., MERKISZ, J., FUC, P. et al. Air pollution by the exhaust emissions from construction machinery under actual operating conditions. Applied Mechanics and Materials. 2013, 390, 313-319.

https://doi.org/10.4028/www.scientific.net/AMM.390.313

[17] MERKISZ, J., LIJEWSKI, P., FUĆ, P. The comparison of the emissions and fuel consumption in vehicles fitted with different powertrain under real operating conditions. Silniki Spalinowe. 2011, 50.

[18] MERKISZ, J., LIJEWSKI, P., FUĆ, P. et al. Development of the methodology of exhaust emissions measurement under RDE (Real Driving Emissions) conditions for non-road mobile machinery (NRMM) vehicles. IOP Conference Series: Materials Science and Engineering. 2016, 148, 012077. https://doi.org/10.1088/1757-899X/148/1/012077

[19] MICHALAK, P., MERKISZ, J., STAWECKI, W. et al. The selection of the engine unit - main engine generator during the modernization of the 19D/TEM2 locomotive. Combustion Engines. 2020, 182(3), 38-46. https://doi.org/10.19206/CE-2020-307

[20] MTU company materials

[21] RYMANIAK, L., SIEDLECKI, M., SOKOLNICKA, B. et al. Comparative test of an internal combustion engine ecological indicators in real operating conditions and on a dynamic engine dynamometer. IOP Conference Series: Materials Science and Engineering. 2018, 421(4), 042069. https://doi.org/10.1088/1757-899X/421/4/042069

[22] SZYMLET, N., LIJEWSKI, P., FUĆ, P. et al. Comparative analysis of passenger car and non-road machinery specific emission in real operating conditions. 2018 International Interdisciplinary PhD Workshop (IIPhDW). IEEE. 2018, 226230. https://doi.org/10.1109/IIPHDW.2018.8388362

[23] WALENTYNOWICZ, J. Propulsion motors for combat vehicles. Journal of KONES Powertrain and Transport. 2006, 13(4), 129-140. https://kones.eu/ep2006_4.html

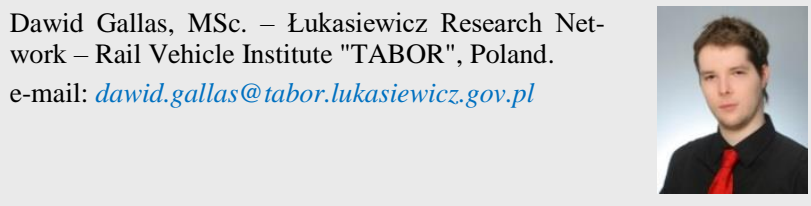

Aleksandra Woch, MEng. - Łukasiewicz Research Network - Rail Vehicle Institute "TABOR", Poland. e-mail: aleksandra.woch@tabor.lukasiewicz.gov.pl

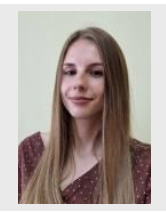

Kuba Mieżowiec, Eng. - Łukasiewicz Research Network - Rail Vehicle Institute "TABOR", Poland. e-mail: kuba.miezowiec@tabor.lukasiewicz.gov.pl

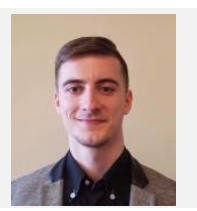

